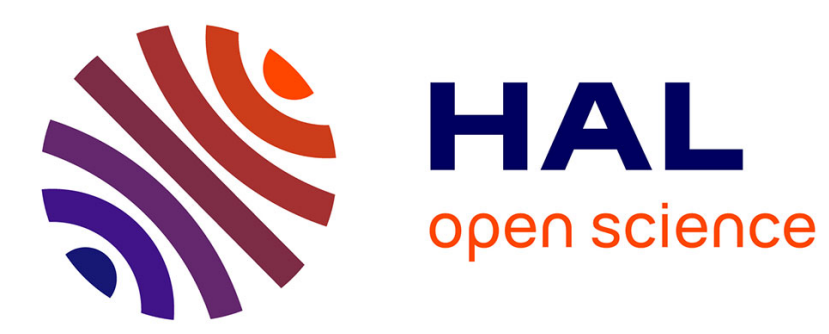

\title{
Optimization of the process control in a semiconductor company. Model and case study of defectivity sampling
}

M'Hamed Sahnoun, Samuel Bassetto, Soidri Bastoini, Philippe Vialetelle

\section{To cite this version:}

M'Hamed Sahnoun, Samuel Bassetto, Soidri Bastoini, Philippe Vialetelle. Optimization of the process control in a semiconductor company. Model and case study of defectivity sampling. International Journal of Production Research, 2010, pp.1. 10.1080/00207543.2010.484429 . hal-00606287

\section{HAL Id: hal-00606287 \\ https://hal.science/hal-00606287}

Submitted on 6 Jul 2011

HAL is a multi-disciplinary open access archive for the deposit and dissemination of scientific research documents, whether they are published or not. The documents may come from teaching and research institutions in France or abroad, or from public or private research centers.
L'archive ouverte pluridisciplinaire HAL, est destinée au dépôt et à la diffusion de documents scientifiques de niveau recherche, publiés ou non, émanant des établissements d'enseignement et de recherche français ou étrangers, des laboratoires publics ou privés. 


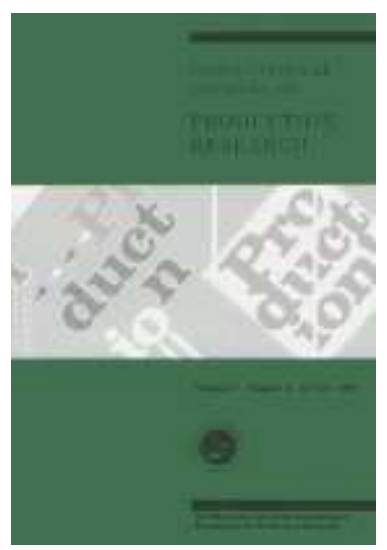

\section{Optimization of the process control in a semiconductor company. Model and case study of defectivity sampling}

\begin{tabular}{|c|c|}
\hline Journal: & International Journal of Production Research \\
\hline Manuscript ID: & TPRS-2009-IJPR-1169.R1 \\
\hline Manuscript Type: & Original Manuscript \\
\hline $\begin{array}{r}\text { Date Submitted by the } \\
\text { Author: }\end{array}$ & 19-Mar-2010 \\
\hline Complete List of Authors: & $\begin{array}{l}\text { Sahnoun, M'Hamed; Grenoble Institute of Technology, Dep. of Ind. } \\
\text { Eng. } \\
\text { Bassetto, Samuel; Grenoble Institute of Technology, Dep. of Ind. } \\
\text { Eng. } \\
\text { Bastoini, Soidri; STMicroelectronics } \\
\text { Vialetelle, Philippe; STMicroelectronics }\end{array}$ \\
\hline Keywords: & $\begin{array}{l}\text { PROCESS CONTROL, QUALITY CONTROL, SEMICONDUCTOR } \\
\text { INDUSTRY, SEQUENCING }\end{array}$ \\
\hline \multicolumn{2}{|l|}{ Keywords (user): } \\
\hline \multicolumn{2}{|c|}{$\begin{array}{l}\text { Note: The following files were submitted by the author for peer review, but cannot be converted } \\
\text { to PDF. You must view these files (e.g. movies) online. }\end{array}$} \\
\hline TPRS-2009-IJPR-1169.R1 tat & les.odt \\
\hline
\end{tabular}

\section{S) ScholaroNE \\ Manuscript Central}




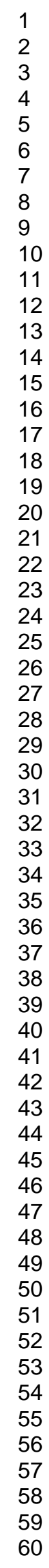

37 


\title{
Optimization of the process control in a semiconductor company. Model and case study of defectivity sampling
}

\author{
M. Shanoun ${ }^{1}$, S. Bassetto ${ }^{1 *}$, S. Bastoini ${ }^{2}$, P. Vialletelle $^{2}$, \\ ${ }^{1}$ Grenoble Inst. of Tech., G-SCOP, CNRS, France \\ ${ }^{2}$ STMicroelectronics, Crolles 300, France
}

\begin{abstract}
This paper studies the skip, under some assumptions, of process control operations. The case of one tool, one enhanced buffer and one metrology tool of a monotonic parameter is analyzed. The paper presents circumstances in which control plan can be optimized due to buffer behavior's. After presenting the industrial issue of defectivity, the article goes through literature review. The article follows by presenting the model and steps toward industrial development. A demonstrator is then presented applied at a case study of defectivity sampling. A test over a $300 \mathrm{~mm}$ wafer-fab data set shows serious improvements: around $35 \%$ of defectivity controls have been allowed to be skipped compared to the static sampling plan.
\end{abstract}

Keywords: Process Control, dynamic control plan, risk measurement, defectivity measurement.

\section{1- Introduction:}

The industrial problem underlying this works find its roots in front-end semiconductor facilities. Particles control is performed over products and tools. After being manufactured, products can be oriented to control devices to release information they held about their cleanness. The result is used to qualify the production system and the product itself. Using data to monitor both products and processes is a common practice in statistical process control and acceptance controls. These measurements are at the heart of defectivity and yield control (Kumar et al. 2006).

Let's consider an oversimplified example: a dust control of a manufacturing equipment $\mathrm{T}$ like an etching tool. The level of contamination, $\mathrm{D}$, increases with the number of items produced. If a product is manufactured on the tool $\mathrm{T}$, it adds particles and can be contaminated by residues. It is controlled after being processed. $\mathrm{T}$ is considered as fouled if the level of $\mathrm{D}$, measured on the

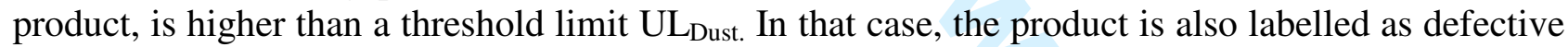
and either can be washed or have to be scrapped. Below this limit, product and tool are both considered as clean. Consider a sequence of 10 products $\mathrm{P}_{1} \ldots \mathrm{P}_{10}$, produced with $\mathrm{T}$ and the associated sampling plan: to-control $\mathrm{P}_{1}$ and $\mathrm{P}_{10} . \mathrm{P}_{1}$ is then produced and controlled. If $\mathrm{P}_{1}$ is clean, then the production planning goes on. If it is measured as defective, a clean operation has to be performed on $\mathrm{T}$ and $\mathrm{P}_{1}$ (if possible). If the cleaning is successful, the production can then be restarted. When $\mathrm{P}_{10}$ is controlled, if $\mathrm{D}$ doesn't reach $\mathrm{UL}_{\text {Dust }}$, as dust has a property of accumulation throughout the production, one can say that $\mathrm{P}_{2}, \mathrm{P}_{3}, \mathrm{P}_{4}, \mathrm{P}_{5}, \mathrm{P}_{6}, \mathrm{P}_{7}, \mathrm{P}_{8}, \mathrm{P}_{9}$ are also clean. If $\mathrm{P}_{10}$ is dirty, then no conclusion can be inferred about previous productions.

Let's change the previous control plan for a $100 \%$ one. The travel between the manufacturing and control system can follow a stochastic law as illustrated Figure 1. B is made of: tool's output buffer, transportation buffer and entrance buffer of the control tool C. The buffer B can behave in a range of stochastic laws. Following Figure 1, the, product $\mathrm{P}_{1}$ is manufactured first and controlled in the fourth position due the buffer behavior. Some products can be controlled before products manufactured earlier. However, as the dust deposition is an increasing phenomena, it is understandable that if product $\mathrm{P}_{4}$ has been released, product $\mathrm{P}_{1}$ is also clean and it is not necessary to control it anymore.

This observation is at the basis of this article.

Corresponding author: Ass. Prof. Samuel Bassetto - samuel.bassetto@ grenoble-inp.fr - tel : +33(0)476574835 -

Grenoble Institute of Technology, Lab. G-SCOP, 46, avenue Félix Viallet 38000 Grenoble, France. 


\section{Figure 1: The production system}

As in semiconductor industry, each pocket of productivity, easy to implement, is always welcome, being able to release controls, without loosing information can help at increasing the productivity in steady state mode and also ramp-up. This paper contributes then to move toward this goal by providing an algorithm to perform this task. A particular measure of operational risks at a tool level and the potential that a measurement has to reduce it has been introduced in order to be able to implement operationally this concept. A model of this case is presented revealing potential gains of this problem.

After this introduction the paper follows with a short literature review. A third part presents the model and associated development to be able to implement it operationally. A fourth part present case study and a discussion.

\section{2- Literature review:}

The article of G. Spanos (Spanos 1991) introduces concepts of process control in Semiconductor industry. A detailed overview of process control tools and practices can also be found with the book of May and Spanos (May \& Spanos 2006). The work of Montgomery (Montgomery 2004) is highly advised to understand concept of SPC, generalized in this industry. In order to design controls and adapt them throughout a technology lifecycle, design economic of control charts and adaptive control chart are two grounding fields of statistical control.

The first one has been initiated by Duncan (Duncan 1956) in 1956. Major drawbacks have been pointed out, (Woodall 1986) toward this design mode and especially the lack of robustness of results. However, grounded with a true problem of balancing controls and their costs, developments have followed. As example, an historical article has been found about quality control skipping (John I.S. Hsu 1977). This paper is concerned with reducing the sample size and decreasing the control frequency, compared to a $100 \%$ or screening plan. It aims at identifying the right control frequency regarding a particular cost model. In the field of economic design of control charts, the model of Lorenzen and Vance (Lorenzen \& Vance 1986) seems to be a milestone paper, as the development of Vommi and Stella (Vommi \& Seetala 2007).

A second development is the adaptation of control plan regarding events observed. Varying sampling interval, sampling frequency or changing of control limits are common actions taken as data are collected. The systematic analysis of this subject began with the publication of Reynolds et al (Reynolds Jr et al. 1988). They demonstrate that a two level of controls (sampling size, frequency, limits) is a better solution to control and detect faster issues while minimizing the cost of errors. Adaptive process control, have been reviewed by Taragas (Tagaras 1998). More recently, Magalhães, Costa, and Moura Neto present also a very clear overview of these technics (De Magalhães et al. 2009) providing a key paper in this field.

In semiconductor industry, several authors focused on control adaptation, yield impact and risks. Based on an economic model which takes into account the reuse of SPC data during for yield and scraps investigations, Baud-Lavigne, Bassetto and Penz, (Baud-Lavigne et al. 2009) present how quality controls can be released due to learning curves. Purdy (M. Purdy 2007), Bousetta and Cross (Bousetta \& Cross 2005), and Mouli and Scott (Mouli \& Scott 2007) present industrial development 
aiming the adaptive control of measurement, regarding yield evolutions, measurement capacity and risks. The first paper, among those three, presents a sampling strategy by counting the number of wafer passed on metrology tools. The second provides a mechanism to update control regarding process excursions. The third presents a generic architecture to update control regarding risks encountered by the production. Their article presents an entire development, which seems to improve quality control performances. Key to their development is the concept of lot environment, they name Partition which is used to compute a risk index. However they do not provide further explanation of the manner they identify the risk index and its representativeness.

All works that authors found about design economic and adaptive sampling are measured by the velocity of control chart detection. The reason why control charts have been settled is hardly or never retrieved in those papers. One present a grounded approach of adaptive quality controls based on yield improvement. One presents a generic approach to risk evaluation but no dot detail the reason why these risks are modeled so and consequences of such a model. None of them is concerned with control skip due to operation control.

The problem presented in introduction can be seen as an inspection re-allocation problem due to buffer's behavior and the variable monitored. Inspection devices can be used to monitor other products than those defined in a static control plan, due to updated information about products. The field of inspection allocation has been investigated since the publication of Lindsay and Bishop, in 1964 (Lindsay \& Bishop 1964). They studied a cost function per unit produced, taking in account the inspection cost and its location in the process. The minimum cost has been found for none inspection or entire batch inspected. Since their paper, several studies have been performed. Close to authors concern, in the field of Printed Circuit Board, Villalobos and al (Villalobos et al. 1993) present a flexible inspection systems for serial and multi-stage production systems. They provide an algorithm based on a Markov Chain model, to optimize global goal (like costs) and local constraints, like inspection tool availability. Verduzco and al. (Verduzco et al. 2001) present an interesting case of information based inspection allocation. They modeled a cost function taking into account the type I and II error linked at each measurement. They simulate their algorithm with a knapsack formulation. They yield that the information based solution reach better performances in term of classification errors that static inspections. Their paper has been a source of inspiration for authors as they introduce the fact that the control strategy can be modified based on its gain. John W. Bean, in his Master Thesis, in MIT (Bean 1997) presents the development of an in-line, dynamic inspection plan, based on the probability of excursions, due to measurement. His work presents also the notion of material at risk (MAR) as each product between two samples can be impacted by defects. In order to be complete, in the field of inspection allocation, authors recommend the surveys of Raz (Tzvi Raz 1986)and Tang and Tang (K. Tang \& J. Tang 1994). Close to the subject is development about automatic control and the position of sensors in the manufacturing process, in order to reduce uncertainty. These models are tightly coupled with diagnosis approaches of Zamaï (ZAMAI 1997). It is assumed that the more the process goes on, the more uncertainty is accumulated, and if it passes a threshold limit, a control has to be performed.

From these fields of researches, no papers have been found related to the release of measurement or inspection due to operation management.

As presented in introduction, measurement operations can be strongly influenced by operation management and especially way buffers production tool and control tool behave. Authors share point of view of Colledani and Tolio (Colledani \& Tolio 2009) that models of quality and quantity are rare in the literature. Hsu and Tapiero (Hsu \& Tapiero 1989) pioneered this field by proposing a link between operation management and SPC control charts. S.B. Gershwin and J. Kim (S.B. Gershwin \& J. Kim 2005) $\square$ and Colledani (Colledani 2008) $\square$ presents academic investigations how quality and operations control can be linked. Especially, the paper of Colledani design the buffer size regarding quality and cycle time expectation. It is based on markov-chain model of a production system, allowing a multiple failure mode behavior's. However, none of these 
works models a possible release of measurements, due to operation management, nor models impact toward risk monitoring.

At the boundary of this research are risk management and production ramp-up. As it inspires authors, the literature goes through - very quickly- these domains.

During the production ramp-up of a transferred or a new technology being able to release control is crucial in order to be able to produce in time. We recommend to readers the industrial article of Bousetta and Cross (Bousetta \& Cross 2005) as an introduction to controls management practices, during ramp-up. We recommend also academic works about the subject: (Terwiesch \& E. Bohn 2001), (Fine 1988), (Tapiero C. S. 1987).

In the same time, almost all semiconductor industrials have to provide updated FMECA(Failure Mode Effects and Criticality Analysis) (Chrysler Corporation, Ford Motor Company, General Motors Corporation 1993), (Department of defense 1980), (Villacourt 1992) about their tool, processes and products in order to ensure their customer, their ability to produce. These analyzes are about operational risk management, which can be defined as the elicitation, evaluation - often through ranking technics - mitigation and follow-up of "fearsome event, regarding stakes" (De Choudens et al. 2000). A general survey of modern methodologies to master risks can be found in (Tixier et al. 2002). Measurements are performed -over products, processes and tools- in order to detect drifts and other possible operational risks occurrence. However very few articles truly link risk analysis and detection. Even in the adaptive controls field, risks are not explicitly mentioned. Only monitored process excursions (out of control events), which are precursors or consequences of operational risks, are monitored (Bean 1997). Pillet (Pillet et al. 2007), pioneered the work of linking control plan at risks. An impact matrix has been presented linking risks and their elicitation at associated control. Ozouf, under the direction of Pillet, follow this path, by providing a deeper analysis of link between risk analyses type and control plan (Ozouf 2009). Bassetto (Samuel Bassetto 2005) proposes an enterprise model joining risks elicitation, their evaluation and associated controls activities. The central idea, is that controls (charts, inspections...) are required due to the fact that tools, processes or products can have or produce failures. Each time one occurs, a revision of risks analysis has to be performed and associated control plans revised. The more risky it is, the more control have to be performed. This framework has been applied by Mili et al, (Mili et al. 2009) for defining maintenance priorities and improvement actions. Application of these models have been tested over a photolithography workshop. This research remains at management level, and doesn't provide details about the manner to update controls, nor ensuring that no instabilities can emerged from this looped system. This issue has also be pointed out by JW Bean (Bean 1997).

At joints of process control - or inspection-, risks management and operation management, research seems very promising, while surprisingly it has been timidly observed by authors in literature. Some researches are closest to the subject of this paper, however, authors haven't retrieved article about the purpose of this article. The quality control release seems to be hardly studied yet and especially its impact in term of information. Of course, industrials can practice an adaptive control, regarding specific risks and their operations without having published their methods other than internal report, unaccessible to authors. May be such practices can also be kept secret, as part of their operational excellence.

\section{3- Model of the dynamic release of some sampling operations}

The purpose of this part is to model and understand deeper the phenomenon presented in introduction in order to move toward a dynamic quality control plan, applied at particle measurement.

Assumption 1: The models under consideration is the case of one production tool, one buffer (made of the output buffer of the manufacturing tool, the transportation buffer - within the plant- the input 
buffer of the metrology tool) and one control device. This model over-simplify the reality but allows first developments.

Assumption 2: The problem of why products are re-scheduled into the buffer, is not taken into account in this article. Several factors are involved, especially, control plan, measurement capacity, transportation, type of information belonging to products. The product's waiting time between manufacturing operation and control operation, is only modeled with a random law $\ell$.

Assumption 3: The metrology tool behave perfectly regarding the phenomenon observed over the product: error I and II are neglected in this first model. The measurement time is considered as constant: $t_{C t r l}$. The information about wafer's cleanness is assumed to be immediately available after the measurement.

Assumption 4: The metrology is performed only over 1 parameter, which behaves in a monotonic manner exclusively with products. In the development below, it is considered as an increasing phenomenon as particles deposition, grease, or painting deposition. The more goods are produced, the more contamination can happened for new products. When possible, decreasing phenomenon are presented in quotes.

Assumption 5: Data obtained on product variables allow to infer information about product functionality and about the way manufacturing tool behave. It is the case of contamination (dust, ionic, grease, etc.) for clean products like wafers or medical devices.

Assumption 6: The test, C, compares the value of a parameter named Def, measured on the $i^{\text {th }}$ product named $\mathrm{P}_{\mathrm{i}}$, with a limit labelled $\mathrm{UL}_{\text {Def }}$. A product is considered as non-defective if its measure is below (or higher) $\mathrm{UL}_{\text {Def }}$ (resp. $\mathrm{LL}_{\mathrm{Def}}$ ). $\mathbf{C}$ is a function from the product space in real C: $\{$ products $\}->$ Real.

Notations: $\mathrm{k}, \mathrm{j}, \mathrm{i}$, three production indices / $\mathrm{k}<\mathrm{j}<\mathrm{i}$

A clearing event is an action like a clean, a washing of the tool or every action that can requalify $\mathrm{T}$ for production. This includes maintenance actions and the dissipation of related effects (as Waddington effect for example).

Property 1: The consequence of the variable's monotonicity is that if a product $\mathrm{P}_{\mathrm{i}}$ is tested and labelled as non-defective, then considering every products $\mathrm{P}_{\mathrm{j}}$, manufactured since the last nondefective product $\mathrm{P}_{\mathrm{k}}$, or the last clearing event, can be considered as correct. Demonstration : if there is a j / j<i \& $\mathrm{C}\left(\mathrm{P}_{\mathrm{j}}\right)>\mathrm{UL}_{\text {Def }}$, by the monotonicity of the phenomenon monitored by $\mathrm{C}$, $\mathrm{C}\left(\mathrm{P}_{\mathrm{i}}\right)>\mathrm{C}\left(\mathrm{P}_{\mathrm{j}}\right)>\mathrm{UL} \mathrm{L}_{\text {Def. }}$. Which is in contradiction with the measurement $\mathrm{C}\left(\mathrm{P}_{\mathrm{i}}\right)<\mathrm{UL} L_{\text {Def.- }}$ The demonstration follows the same pattern for a decreasing phenomenon with $\mathrm{LL}_{\mathrm{Def}}$.

If assumption 3 cannot be assumed, then this property has to be modified for a stochastic approach.

As a consequence of this property, if the information retrieved by the measurement is to compare these products toward $\mathrm{UL}_{\text {Def }}$, (resp $\mathrm{LL}_{\mathrm{Def}}$ ) it is unnecessary to control them. The measurement can be skipped. When a product is scrutinized and considered as clean, products manufactured since the last qualification operation (maintenance or following a bad production detection) are also labelled as clean. At the opposite, if a product is measured as faulty or fouled, an investigation has to begin, every product before it can be contaminated. In a sceptic perspective, when a product is not measured, it joins the set of potentially bad products.

Mixed with a stochastic behavior of the buffer $\mathrm{B}$ (see Figure 1), $\mathrm{P}_{\mathrm{i}}$ has a non null probability to be 
measured before $\mathrm{P}_{\mathrm{j}}$. The previous property can generates release of controls and by the way gains.

However these developments only point out possible improvement. Let's go further in the investigation of behavior and system performances (Li \& Meerkov 2009), by introducing some complementary notations and assumptions.

Assumption 7: the model is made between two qualification actions or clearing events. The time elapsed between these two actions is named production cycle and noted PC. Indices of product within a Process Cycle, start at 1 .

Assumption 8: For the sake of simplification, $\mathrm{T}$ produces goods in a regular manner every $\tau$ second, and follows a non stochastic behavior. We consider that $\tau \square \mathrm{PC}$. During PC, T produces PC/ $\tau$ products.

Assumption 9: The control plan is set at $100 \%$. Every manufactured product has to be measured.

Assumption 10: The probability that a $\mathrm{i}^{\text {th }}$ product is clean depends on the number of products produced before, since the last clearing event, and due to assumption 7, the beginning of the process cycle.

$\mathrm{p}\left(\mathrm{P}_{\mathrm{i}}\right.$ is clean $) \square(1 / \mathrm{Number} \text { of items produced since last clearing event })^{\alpha}$, where $\alpha$ is a parameter $\mathrm{p}\left(\mathrm{P}_{\mathrm{i}}\right.$ is clean $) \square(1 / \mathrm{i})^{\alpha}$ as a consequence of assumption 7 .

The buffer B, follows a stochastic law, noted $\boldsymbol{\ell}$. The probability that a product goes out of $\mathrm{B} \mathrm{t}_{\mathrm{B}}$ time after being entered, is given by the formula $: \mathrm{p}=\int_{0}^{\mathrm{tb}} \ell(\mathrm{x}) \mathrm{dx}$.

Let's note: $t_{C}\left(P_{i}\right)$, the time where the information about $P_{i}$ is available. $t_{P}\left(P_{i}\right)$ the time when $P_{i}$ is manufactured and $t_{B}\left(P_{i}\right)$ the time elapses by $P_{i}$ within the buffer $B$.

Property 1 can be transformed as follow:

$\square(\mathrm{i}, \mathrm{j}) \square[1 ; \mathrm{PC} / \tau]^{2} / \mathrm{j}>\mathrm{i}, \mathrm{P}_{\mathrm{i}}$ can be released if and only if condition 1 and 2 are verified:

Condition $1: \mathrm{t}_{\mathrm{C}}\left(\mathrm{P}_{\mathrm{j}}\right) \leq \mathrm{t}_{\mathrm{C}}\left(\mathrm{P}_{\mathrm{i}}\right)$

Condition 2: $\mathrm{P}_{\mathrm{j}}$ is clean

Let's now evaluate the probability that these two conditions are true for a particular product.

\section{Probability of Condition 1:}

$\mathrm{t}_{\mathrm{P}}\left(\mathrm{P}_{\mathrm{i}}\right)=\mathrm{i} * \tau, \mathrm{t}_{\mathrm{P}}\left(\mathrm{P}_{\mathrm{j}}\right)=\mathrm{j} * \tau$

the buffer $\mathrm{B}$ behaves as a delay generator.

$\mathrm{t}_{\mathrm{C}}\left(\mathrm{P}_{\mathrm{i}}\right)=\mathrm{t}_{\mathrm{B}}\left(\mathrm{P}_{\mathrm{i}}\right)+\mathrm{t}_{\mathrm{P}}\left(\mathrm{P}_{\mathrm{i}}\right)=\mathrm{t}_{\mathrm{B}}\left(\mathrm{P}_{\mathrm{i}}\right)+\mathrm{i}^{*} \tau+\mathrm{t}_{\mathrm{C} \text { trl }}$

$\mathrm{t}_{\mathrm{C}}\left(\mathrm{P}_{\mathrm{j}}\right)=\mathrm{t}_{\mathrm{B}}\left(\mathrm{P}_{\mathrm{j}}\right)+\mathrm{t}_{\mathrm{P}}\left(\mathrm{P}_{\mathrm{j}}\right)=\mathrm{t}_{\mathrm{B}}\left(\mathrm{P}_{\mathrm{j}}\right)+\mathrm{j} * \tau+\mathrm{t}_{\mathrm{Crrl}}$

Condition 1 is verified $\square \mathrm{t}_{\mathrm{C}}\left(\mathrm{P}_{\mathrm{j}}\right) \leq \mathrm{t}_{\mathrm{C}}\left(\mathrm{P}_{\mathrm{i}}\right) \square \mathrm{t}_{C \text { trr }}+\mathrm{t}_{\mathrm{B}}\left(\mathrm{P}_{\mathrm{j}}\right)+\mathrm{j} * \tau \leq \mathrm{t}_{\mathrm{B}}\left(\mathrm{P}_{\mathrm{i}}\right)+\mathrm{i}^{*} \tau+\mathrm{t}_{\mathrm{Crr}} \square \mathrm{t}_{\mathrm{B}}\left(\mathrm{P}_{\mathrm{j}}\right) \leq \mathrm{t}_{\mathrm{B}}\left(\mathrm{P}_{\mathrm{i}}\right)-\tau *(\mathrm{j}-\mathrm{i})$

In term of probability that these event occurs for the product $\mathrm{P}_{\mathrm{i}}$,

Case 1: $\left.\tau^{*}(\mathrm{j}-\mathrm{i})>\mathrm{t}_{\mathrm{B}}\left(\mathrm{P}_{\mathrm{i}}\right) ;{ }^{*}\right)$ cannot be verified and $\mathrm{p}\left(\mathrm{t}_{\mathrm{C}}\left(\mathrm{P}_{\mathrm{i}}\right)>\mathrm{t}_{\mathrm{C}}\left(\mathrm{P}_{\mathrm{j}}\right)\right)=0$, $\mathrm{P}_{\mathrm{i}}$ cannot be released for control,

Case 2: $\tau^{*}(\mathrm{j}-\mathrm{i})=\mathrm{t}_{\mathrm{B}}\left(\mathrm{P}_{\mathrm{i}}\right) ; \mathrm{p}\left(\mathrm{t}_{\mathrm{C}}\left(\mathrm{P}_{\mathrm{i}}\right)=\mathrm{t}_{\mathrm{C}}\left(\mathrm{P}_{\mathrm{j}}\right)\right)=\mathrm{p}\left(\mathrm{t}_{\mathrm{B}}\left(\mathrm{P}_{\mathrm{j}}\right)=0\right), \mathrm{L}(0)=\int_{0}^{0} \ell(\mathrm{x}) \mathrm{dx}$.

Case 3: $\tau^{*}(\mathrm{j}-\mathrm{i})<\mathrm{t}_{\mathrm{B}}\left(\mathrm{P}_{\mathrm{i}}\right)$; the probability that the time elapse by $\left(\mathrm{P}_{\mathrm{j}}\right)$ within the buffer is below $\mathrm{t}_{\mathrm{B}}\left(\mathrm{P}_{\mathrm{i}}\right)-$ 
$\tau^{*}(\mathrm{j}-\mathrm{i}) \square \tau^{*}(\mathrm{j}-\mathrm{i})<\mathrm{t}_{\mathrm{B}}\left(\mathrm{P}_{\mathrm{i}}\right) ; \mathrm{p}\left(\mathrm{t}_{\mathrm{C}}\left(\mathrm{P}_{\mathrm{i}}\right)>\mathrm{t}_{\mathrm{C}}\left(\mathrm{P}_{\mathrm{j}}\right)\right) \square \mathrm{p}\left(\mathrm{t}_{\mathrm{B}}\left(\mathrm{P}_{\mathrm{j}}\right)\right)<\int_{0}^{\mathrm{tb}(\mathrm{Pi})-\tau(\mathrm{j}-\mathrm{i})} \ell(\mathrm{x}) \mathrm{dx}$

These 3 cases are valid for every product manufactured within the Process Cycle.

Probability of condition 2:

$\mathrm{P}_{\mathrm{j}}$ has also to be clean. However, the last clearing event has to be anterior to i. In the contrary, nothing could be inferred from the cleanness of $P_{j}$.

$\mathrm{p}\left(\mathrm{P}_{\mathrm{j}}\right.$ is clean $) \square(1 / \text { Number of items produced since last clearing event })^{\alpha}=(1 / \mathrm{j})^{\alpha}$

\section{Probability for a particular product $P_{i}$ to verify condition 1 and condition 2 , and to be released}

Let's note $R$, the set of products which can be released. During the production, $R$ increases as products verify conditions 1 and 2 . After a Process Cycle, $R=\left\{\mathrm{P}_{\mathrm{i}} / \mathrm{i} \square[1 ; \mathrm{PC} / \tau] \& \square \mathrm{j} \square[1 ; \mathrm{PC} / \tau] / \mathrm{j}>\mathrm{i} \&\right.$ $\mathrm{t}_{\mathrm{B}}\left(\mathrm{P}_{\mathrm{j}}\right)<\int_{0}^{\mathrm{tb}(\mathrm{Pi}) \tau \tau(\mathrm{j}-\mathrm{i})} \ell(\mathrm{x}) \mathrm{dx} \& \mathrm{P}_{\mathrm{j}}$ is clean $\}$.

A particular product $P_{i}$ belongs to $R$, if there is at least one product, produced after $P_{i}$ that is measured before and if it is clean. These products can be $\mathrm{P}_{\mathrm{i}+1} \mathrm{P}_{\mathrm{i}+2} \ldots \mathrm{P}_{\mathrm{k}^{*}}$, where $\mathrm{k}^{*}$ /

- the last product is produced within the Process Cycle : $\mathrm{k}^{*} \leq \mathrm{PC} / \tau$

- the time elapse between $\mathrm{P}_{\mathrm{i}}$ and $\mathrm{P}_{\mathrm{k}^{*}}$ is at the limit of $\mathrm{P}_{\mathrm{i}}$ 's waiting time within the buffer:

$$
\begin{array}{ll}
\text { - } & \mathrm{t}_{\mathrm{B}}\left(\mathrm{P}_{\mathrm{i}}\right)>\tau\left(\mathrm{k}^{*-\mathrm{i}}\right) \\
\text { - } & \mathrm{t}_{\mathrm{B}}\left(\mathrm{P}_{\mathrm{i}}\right) \leq \tau\left(\mathrm{k}^{*}+1-\mathrm{i}\right)
\end{array}
$$

The probability that $P_{i}$ belongs to $R=p\left(P_{i} \square R\right)$

$\square \mathrm{p}\left(\left[\mathrm{P}_{\mathrm{i}+1}\right.\right.$ reach $\mathrm{C}$ before $\mathrm{P}_{\mathrm{i}}$ and $\mathrm{P}_{\mathrm{i}+1}$ is clean $]$ or $\left[\mathrm{P}_{\mathrm{i}+2}\right.$ reach $\mathrm{C}$ before $\mathrm{P}_{\mathrm{i}}$ and $\mathrm{P}_{\mathrm{i}+2}$ is clean $] \ldots$ or $\left[\mathrm{P}_{\mathrm{k}^{*}}\right.$ reach $C$ before $P_{i}$ and $P_{k *}$ is clean])

$\square \sum_{\mathrm{m}=\mathrm{i}+1} \mathrm{k}^{*} \mathrm{p}\left(\mathrm{P}_{\mathrm{i}+\mathrm{m}}\right.$ reaches $\mathrm{C}$ before $\mathrm{P}_{\mathrm{i}}$ and $\mathrm{P}_{\mathrm{i}+\mathrm{m}}$ is clean $)$

$\left.\sum_{\mathrm{m}=\mathrm{i}+1}^{\mathrm{k}^{*}} \mathrm{p}\left(\mathrm{t}_{\mathrm{B}}\left(\mathrm{P}_{\mathrm{m}}\right)<\int_{0}^{\mathrm{tb}(\mathrm{Pi})-\tau(\mathrm{m}-\mathrm{i})} \ell(\mathrm{x}) \mathrm{dx}\right)\right)^{*} \mathrm{p}\left(\mathrm{P}_{\mathrm{i}+\mathrm{m}}\right.$ is clean $)$

In order to consider the equivalence, let's take the case where $\mathrm{p}\left(\mathrm{P}_{\mathrm{j}}\right.$ is clean $)=(1 / \mathrm{j})^{\alpha}$

$\left.\square \sum_{\mathrm{m}=\mathrm{i}+1}{ }^{\mathrm{k}^{*}} \mathrm{p}\left(\mathrm{t}_{\mathrm{B}}\left(\mathrm{P}_{\mathrm{m}}\right)<\int_{0}^{\mathrm{tb}(\mathrm{Pi})-\tau(\mathrm{m}-\mathrm{i})} \ell(\mathrm{x}) \mathrm{dx}\right)\right)^{*}(1 /(\mathrm{i}+\mathrm{m}))^{\alpha}$

\section{Algorithm:}

This formulation is generic for every product being produced within a process cycle. In order to determine Card $R$, this probability has to be evaluated for every product manufactured in a cycle. This sum, can be simulated knowing $\ell,{ }^{\alpha}$. Of course, $t_{B}\left(P_{i}\right)$ are defined when the simulation reaches the $i^{\text {th }}$ step. The algorithm is presented in Annex.

As the buffer behave in a stochastic manner, there is no reasons that this probability is systematically null, then Card $R \geq 0$. As the initial control rate was 1 considering that Card $(R) \geq 0$, the new sampling rate is $[1-\operatorname{card} \mathrm{R} /(\mathrm{PC} / \tau)]$.

Several problems are encountered at this level:

- To determine Card $R$ in an exact manner.

- The evaluation of $\mathrm{p}\left(\mathrm{P}_{\mathrm{i}}\right.$ is clean $)$ depends heavily on the way the risk monitored behave. Other probability function could have been chosen.

\section{Illustrative example, based on the simulation}

From the $1^{\text {st }}$ product to the $1^{\text {st }}$ Control. The control plan is set at $100 \%, \alpha=0,5, \tau=1$

In this simulation, $\mathrm{t}_{\mathrm{C}}\left(\mathrm{P}_{\mathrm{i}}\right)$ is known, leading at a ranking of product behind measurement tool.

The product 1 is produced at 1 and controlled at time 58. The product 2 is produced at 2 and 
controlled at time 5...It is clear that in this list, the second product is the first to be measured. Its probability of being clean follows the law of assumption 10, which leads at 0,7. As the measurement retrive a value below this limit, the product is considered as clean. By the way, the first product is also declared as clean and skipped from control.

First Measurement - Table 1:

\section{Table 1. First measurement}

The buffer's output is reordered for the second control.

Second Measurement - Table 2

According to the fourth left-hand column, the second measurement occurs on the eights product. Its probability of being clean equals 0,35 . As the measurement retrieve 0,3 , it is declared as clean and by the way its predecessors also. This involves:

- Product 9 and 10 are moved from respectively from the 4th and 7th position to the 3 and 4 th ones.

- Controls of product 3 to 7 are skipped

Table 2. Second measurement

Third Measurement - Table 3

For this measurement, the $9^{\text {th }}$ product is measured and its probability of being clean is 0,31 . The measurement retrieve 0,6 , which leads at a clearing event.

- Controls of product 3 to 7 are skipped

Table 3. Third measurement 
The $3^{\text {rd }}$ measurement reveals a fouled tool. A cleaning action is performed and the process cycle is restarted. The probability of being clean is now $(1 / 1)^{\wedge} 0.5=1$

Fourth Measurement - Table 4

The fourth measurement is then made for a new cycle, as a clearing event occurs at the third measurement.

Table 4. Fourth measurement

In this example, 6 products have been skipped, over 10, without loss of information.

This part presents under some assumptions, that some controls can be skipped due to properties of the underlying phenomenon, without impacting information generation. A general formulation has been presented and a fake example illustrates the purpose. However in order to provide exact solutions, further investigations have to be continued. The probability presented in this part, is hardly obtained in real situations. It can be used for estimating a potential return on investment.

\section{4- Toward an industrial application:}

In order to operate properties presented above, another decision tool is introduced. As mentioned previously, while a product has not been measured, it is considered as suspect, and the tool also. A $100 \%$ sampling plan is often an utopia for process control activities. Sampling involves that some products are not controlled and can be revealed as defective after having followed their production plan. A risk estimator is employed to ensure operational understanding sampling impact. At operation level, the main focus is on amount of product processed and potentially impacted by a fault. This estimator counts the number of potentially bad products. It measures the risk of impact. It is not an estimator of the behavior of the monitored phenomenon, in this case, the defectivity. The probability that a product has been contaminated is independent of this indicator. An illustration of this indicator is provided Figure 2. This counter is also known as Material At Risk (Bean 1997), and named operationally wafers at risks.

This concept is threefold:

- From T point of view, each time it operates a product, a counter, named $I R \square T \sqsubset$ is increased. It is the number of products potentially impacted by the drift of the tool. In the remainder, it will also be named "risk indicator for the tool T". It depends of the number of products manufactured.

- From the product, when it is manufactured, it sees of the value of the risk at the time it is 
processed. $I R P_{i} \notin I R \square T \square_{i}$ Each time a product is controlled, due to assumption 5, this indicator evolves.

- Let's note $I R_{r} P_{i} \sqsubset$, the amount of $I R \sqsubset T \sqsubset$ reduction, associated at a measure and release of $P_{i}$. This measure is central to evaluate the information held by product.

With such definitions, there is a direct correspondence between information added by a product and risk taken by producing or controlling. This indicator has been and remains central to the communication with operational teams about the skipping action, as easier to manipulate than probabilities.

At time i, if the product is immediately controlled after being produced, if it is declared as clean, and if it is the first product to be measured since the last tool $\mathrm{T}$ qualification, then products produced before are released : $I R_{r} \square P_{i} \boxminus I R \square T \square_{i}$. Considering that a product $\mathrm{P}_{\mathrm{i}}$ add to $I R T_{i}, \mathrm{f}\left(\mathrm{P}_{\mathrm{i}}\right)$ (typically $\mathrm{f}$ is a step 1 function, if tool operates one product per operation).

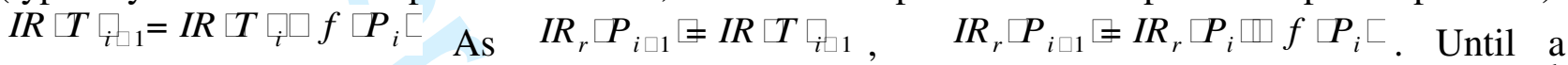
measurement is performed values of risk reduction remain unchanged. By recurrence for the $h^{\text {th }}$ product (implicitely produced at time $\mathrm{h}$, and not notified here):

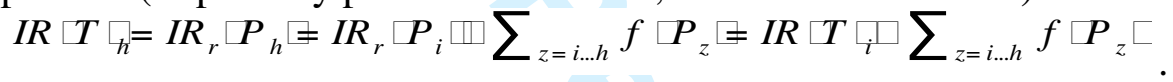

This equation links a risk reduction potential at a time $h$, at the risk indicator of the tool at a predefined passed time $\mathrm{i}$, in function of the production during $\mathrm{i}$ and $\mathrm{h}$. While $\mathrm{P}_{\mathrm{i}}$, hasn't been controlled, it enters in the risk reduction calculation for next products.

As each measurement makes the system evolve. Let's introduces some complementary notations : $\mathrm{t}_{\mathrm{C}}\left(\mathrm{P}_{\mathrm{i}}\right)$ is noted $\mathrm{k}$

The measurement of $\mathrm{P}_{\mathrm{i}}$, is available at time $\mathrm{k}$ : $\mathrm{C}\left(\mathrm{P}_{\mathrm{i}}, \mathrm{k}\right)$.

$\square . .{ }_{k}$ - notation for values just before the measurement at time $\mathrm{k}$

$\square . . k_{\square}$ notation for values just after measurement at time k. For example:

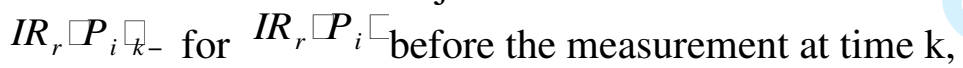

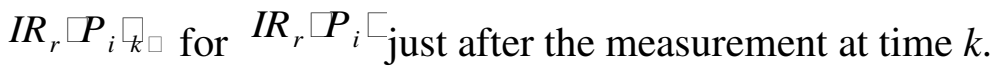

When a measurement occurs:

Case 1: If the product $\mathrm{P}_{\mathrm{i}}$ is measured before product $\mathrm{P}_{\mathrm{h}}$, at time $\mathrm{k}(\mathrm{k} / \mathrm{k}>\mathrm{h}>\mathrm{i})$, and if $\mathrm{C}\left(\mathrm{P}_{\mathrm{i}}, \mathrm{k}\right)<\mathrm{UL}_{\text {Def }}$ it is declared as clean. This will modify the equation above.

$I R_{r} \square_{i} \square_{\square}=0$ and $\sum_{z=i \ldots k} f P_{z} \square_{k-}=\sum_{z=i \ldots k} f P_{z} \square_{k} \square$ remains unchanged as these product have been manufactured after $\mathrm{P}_{\mathrm{i}}$.

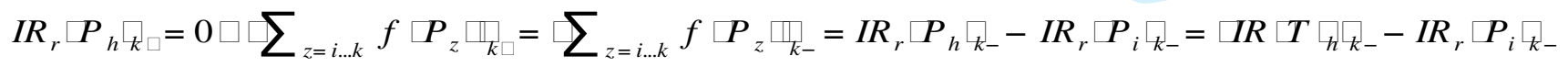

The risk indicator is decreased of the value of $I R_{r} P_{i} \square_{k}$ and $I R_{r} \square P_{h} \rrbracket_{k} \square 0$. This case is presented Figure 2. 
Figure 2: Risk indicator update when products order is not revised

Case 2: If the product $\mathrm{P}_{\mathrm{h}}$ is measured first and $\mathrm{C}\left(\mathrm{P}_{\mathrm{h}}, \mathrm{k}\right)<\mathrm{UL}$ Def . If $\mathrm{P}_{\mathrm{h}}$ is declared "clean", then due to the property demonstrated before, every product produced and not measured before can be released.

In the example of 10 products, the release of $\mathrm{P}_{10}$, validates also $\left\{\mathrm{P}_{2} \ldots \mathrm{P}_{9}\right\}, 8$ products. By the way, $I R \square T \sqsubset_{\text {is }}$ decreased of $8 . \quad I R_{r} P_{10} \square_{10-}=8$. After this measurement, $I R_{r} P_{2} \square_{10 \square}=I R_{r} \square_{3} \square_{0 \square}=\ldots I R_{r} \square P_{9} \square_{10 \square}=0$.

$I R_{r} P_{i} \square_{k}=0$ and $I R \square T \square_{k \square}=0$ if $\mathrm{h}$ is the first product to be measured since the beginning of the production. This situation is presented Figure 3, where product 3 is measured before product 2, releasing it for production.

\section{Figure 3: Risk reduction variation}

The skip action: The action of case 2 , for product $\mathrm{P}_{\mathrm{i}}$, is named : "skipping". It is the drop of a control action, as the operation will not modify this indicator.

This indicator helps in clarifying the manner to operationalize previous property. Case one can be used to choose among a list of products to be measured, which one will induce the highest risk reduction. Case two induce the skip of a measurement.

\section{The application and discussion}

The case study takes place in a research an production semiconductor plant of STMicroelectronics in France. This facility is a Front-End Semiconductor $300 \mathrm{~mm}$ wafer fab. The case considers defectivity control, for etching tool. Defectivity is performed over several measurement devices, which will be assimilated at 1 single tool. The risk indicator is a counter of wafers, manufactured by 
the tool. Due to handling operations (automatic, or manual) and products priorities the time spent between the end of the manufacturing operation and the measurement one is very variable. It can happens that some lots produced in the afternoon are measured before lots produced in the morning, and the case 2 , mentioned above seems to occurs frequently.

Case study assumptions: The case is limited at one manufacturing device, one defectivity tool. Products are assimilated here at lots of products, often made of 25 wafers. A lot intended for the defectivity carries only one information about the manufacturing tool which is the "wafer at risk reduction" noted $I R_{r}$.

A test computes $I R$ in real time and perform the skip where possible has been realized central to this algorithm is the computation of condition 1 and condition 2 for each product observed. It uses real data from STMicroelectronics. It is presented Figure 4. In this figure, reader can see two x-axes for the time. The axe above is made of production's time. It is not linear and depend only of the times when products are manufactured. The second axe is the actual time. In this axe, measurements are represented with circles.

Figure 4: IR prototype

The interface, presented Figure 4, shows in real-time a graphical representation of the movement of lots in production, those waiting for the defectivity measurement and the evolution of $I R$.

In a first test, a data set has been prepared in order to run the algorithm. Over a 12 days period, one case allowed to be skipped has been introduced. Lots intended to be measured and their true entrance into measurement devices are presented in green. Lot intended to be skipped are flagged with a red line, as illustrated Figure 5. Lots actually skipped are represented with a white circle. The test has been successful. The lot fulfilling condition 1 and condition 2, has been identified and skipped as presented Figure 5.

Figure 5: Zoom on case of skip 
The algorithm has been run over 2 months of production. During that period, 14292 wafers have been flagged for defectivity measurement. The application of this algorithm showed that 5024 wafers could have been released for production as they didn't add any new information. The algorithm released $35 \%$ of lots flagged for defectivity compared to the static sampling plan. Card $\mathrm{R} /(\mathrm{PC} / \tau) \square 35 \%$. This mean that $35 \%$ of these lots have been controlled, without adding any information and have cost in term of measurement capacity, due to the fixed sampling.

The industrial application of the property demonstrated in this paper, is more concerned with the evaluation of the number of potentially infected wafers. However results are promizing as Card $R$ is far from 0 . The real case shows potential improvement and actual cost reduction of defectivity measurement.

There is then a deep interaction between manufacturing scheduling, and buffer behavior's leading at the release of controls, without losses of information.

Particular development are ongoing:

- The impact of the stochastic behavior of the buffer allows to release some controls, as they will not add any information regarding risks. However, regarding buffer's characteristics (mean time, variability, behavior's law, etc.) and regarding a specific production plan, the gain of capacity could be calculated.

- The impact of some assumption modifications as variable monotonicity and metrology tool behavior.

Even if semiconductor industry generated the case study, every situation, which fit assumptions presented for the model could apply the skip algorithm.

\section{5- Conclusion:}

This paper presents a one tool, one buffer and one measurement device production system. It investigates a particular property of this system under 11 assumptions, in order to raise a class of problems and especially the variation of sampling rate, without the loss of information due to a stochastic behavior of the buffer. In order to operationalize this concept, a risk index is introduced and a case study is presented in a semiconductor manufacture. The measurement is defectivity control. The article ends with a special opening concerning the quantification of gains, in advance, by identifying buffer's behavior and its impact on capacity release.

\section{Acknowledgement:}

Authors are warmly grateful to STMicroelectronics for providing data and support in their research.

This paper describes work undertaken in the context of the IMPROVE project, "ImplementingManufacturing science solutions to increase equiPment pROductiVity and fab pErformance" . IMPROVE is a JTI Project supported by the ENIAC Joint Undertaking, contract number: 12005. 


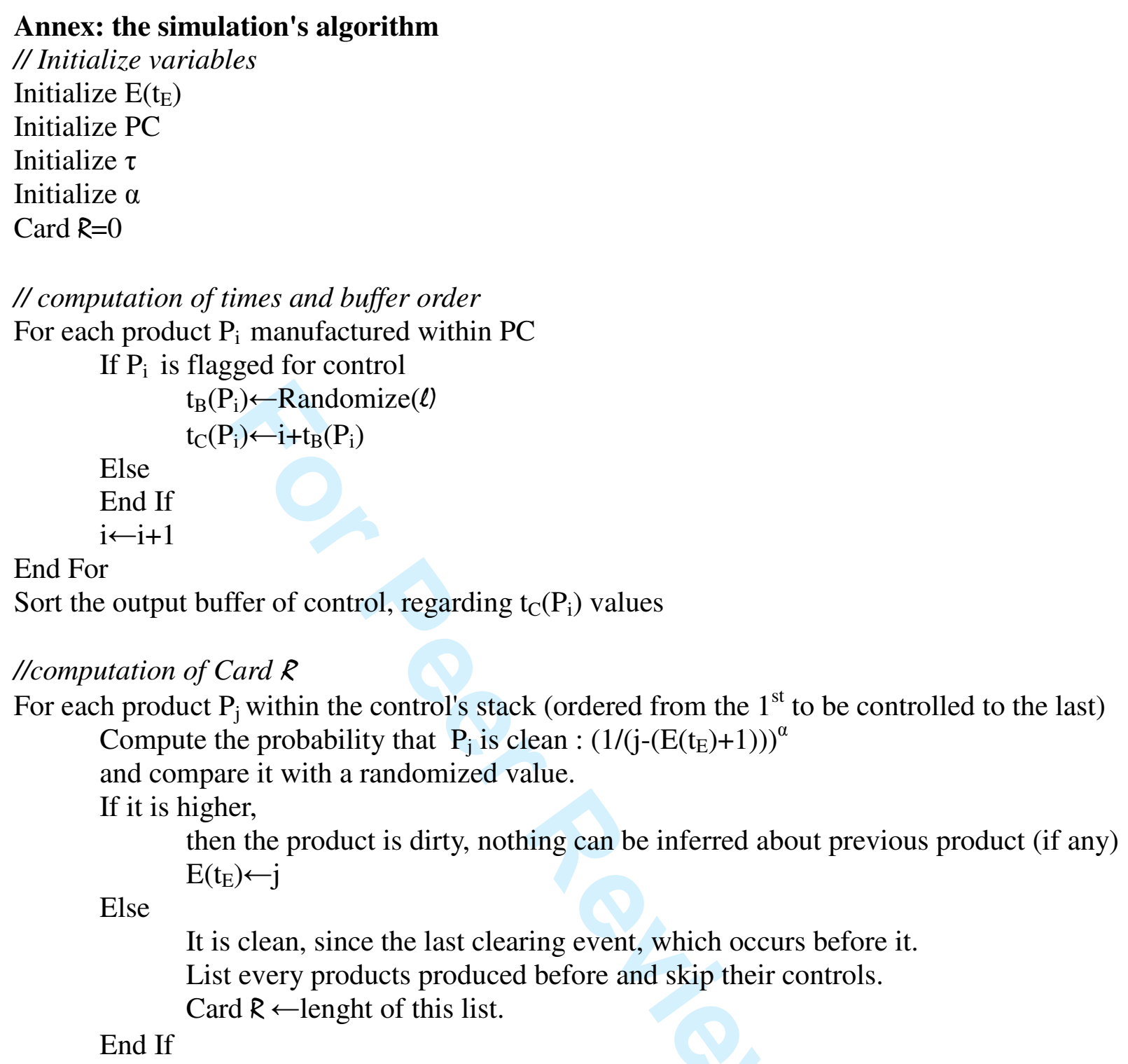

End For

This algorithm works is not a real time. It is employed to evaluate the gain only. 


\section{Annex: the prototype algorithm}

For each product produced

- Compute IR(T)

- Store time at which a cleaning event occurs

- Each time a measurement occurs, evaluate $\operatorname{Ir}(\mathrm{Pi})$, for product waiting for measurement since the last clearing event

- If $\operatorname{Ir}(\mathrm{Pi})=0$, then release the product.

- Else let the product in the control buffer 


\section{References:}

Bassetto, S., 2005. Toward a dynamic, operational and embeded knowledge manufacturing improvement. PhD Thesis. ParisTech (in French).

B. Baud-Lavigne, S. Bassetto, et B. Penz, A broader view of the economic design of the X-bar chart in the semiconductor industry, International Journal of Production Research, 2009.

Bean W. J., 1997. Variation reduction in a wafer fabrication line through inspection optimization. Thesis. M.I.T.

Bousetta, A. \& Cross, A., 2005. Adaptive sampling methodology for in-line defect inspection. Dans Advanced Semiconductor Manufacturing Conference and Workshop, 2005 IEEE/SEMI. pp. 25-31.

Chrysler Corporation, Ford Motor Company, General Motors Corporation, 1993. Potential Failure Mode and Effects Analysis, Reference Manual

Colledani, M., 2008. Integrated Analysis of Quality and Production Logistics Performance in Asynchronous Manufacturing Lines. IFAC World Congres, Seoul, pp. 1-7.

Colledani, M. \& Tolio, T., 2009. Performance evaluation of production systems monitored by statistical process control and off-line inspections. International Journal of Production Economics, In Press, DOI 10.1016/j.ijpe.2007.07.011

De Choudens, H. et al., 2000. Natural and technologic Disasters, information for a better prevention. (In French). Institut des Risques Majeurs, Grenoble.

De Magalhães, M., Costa, A. \& Moura Neto, F., 2009. A hierarchy of adaptive control charts. International Journal of Production Economics, 119(2), 271-283.

Department of defense, 1980. Procedures for performing a Failure Mode, Effects, and Criticality Analysis. MILSTD 1629A

Duncan, A.J., 1956. The Economic Design of X-bar Charts used to Maintain Current Control of a Process. Journal of the American Statistical Association, 51(274), 228-242.

Fine, C.H., 1988. A quality control model with learning effects. Oper. Res., 36(3), 437-444.

Hsu, L. \& Tapiero, C.S., 1989. Quality control of the M/G/1 queue. European Journal of Operational Research, 42(1), 88-100.

John I.S. Hsu, A cost model for Skip-lot Destructive Sampling, IEEE Transactions on reliability, vol. 26, Avr. 1977.

N. Kumar, K. K., K. Gildersleeve, R. Abelson, C. M. Mastrangelo, et D.C. Montgomery, A review of yield modelling techniques for semiconductor manufacturing, International Journal of Production Research, vol. 23, Déc. 2006, pp. 5019-5036.

Li, J. \& Meerkov, S.M., 2009. Production Systems Engineering Springer., New York. 
Lindsay, G.F. \& Bishop, A.B., 1964. Allocation of Screening Inspection Effort-A DynamicProgramming Approach. Management Science, 10(2), 342-352.

Lorenzen, T.J. \& Vance, L.C., 1986. The Economic Design of Control Charts: A Unified Approach. Technometrics, 28(1), 3-10.

M. Purdy, 2007. Dynamic, weight-based sampling algorithm.ISSM 2007. International Symposium on Semiconductor Manufacturing. pp. 1-4.

May, G.S. \& Spanos, C.J., 2006. Fundamentals of semiconductor manufacturing and process control IEEE., New Jersey: Wiley-interscience.

Mili, A. et al., 2009. Dynamic risk management unveil productivity improvements. Journal of Loss Prevention in the Process Industries, 22(1), 25-34.

Montgomery, D., 2004. Introduction to Statistical Quality Control 5 éd., John Wiley \& Sons.

Mouli, C. \& Scott, M., 2007. Adaptive Metrology Sampling techniques enabling higher precision in variability detection and control. Dans Advanced Semiconductor Manufacturing Conference, 2007. ASMC 2007. IEEE/SEMI. pp. 12-17.

Ozouf, V., 2009. How to warrant an acceptable risk level in an ever shrinking development environment and complexity increasing environment (in French). Savoie University.

Pillet, M. et al., 2007. Impact matrix for designing control plan (in French). CPI, Rabat, Maroc.

Reynolds Jr, M.R. et al., 1988. X Charts with Variable Sampling Intervals. Technometrics, 30(2), 181-192.

S.B. Gershwin \& J. Kim, 2005. Integrated Quality and Quantity Modeling of a Production Line. OR Spectrum, 27, 287-314.

Spanos, C.J., 1991. Statistical process control in semiconductor manufacturing. Microelectronic Engineering, 10(3-4), 271-276.

Tagaras, G., 1998. A survey of recent developments in the design of adaptive control charts. Journal of quality technology, 30(3), 212-231.

Tang, K. \& Tang, J., 1994. Design of Screening Procedures: A review. Journal of quality technology, 26(3), 209-247.

Tapiero C. S., 1987. Production learning and quality control. IIE transactions, 19(4), 362-270.

Terwiesch, C. \& E. Bohn, R., 2001. Learning and process improvement during production ramp-up. International Journal of Production Economics, 70(1), 1-19.

Tixier, J. et al., 2002. Review of 62 risk analysis methodologies of industrial plants. Journal of Loss Prevention in the Process Industries, 15(4), 291-303.

Tzvi Raz, 1986. A Survey of Models for Allocating Inspection Effort in Multistage Production Systems. Journal of quality technology, 18(4), 239-247. 
Verduzco, A., Villalobos, J.R. \& Vega, B., 2001. Information-based inspection allocation for realtime inspection systems. Journal of Manufacturing Systems, 20(1), 13-22.

Villacourt, M., 1992. Failure Mode and Effects Analysis (FMEA): A Guide for Continuous Vine Improvement for the Semiconductor Equipment Industry SEMATECH.

Villalobos, J.R., Foster, J.W. \& Disney, R.L., 1993. flexible inspection system for serial multistage production systems. IIE - Transactions, 25(3), 16.

Vommi, V.B. \& Seetala, M.S., 2007. A new approach to robust economic design of control charts. Applied Soft Computing, 7(1), 211-228.

Woodall, W., 1986. Weaknesses of the economic design of control charts. TECHNOMETRICS, 28(4), 408-409.

Zamaï, E. Monitoring-Command architecture for complex discrete events systems (In French), PhD thesis, Grenoble University, 1997Bassetto, S., 2005. Toward a dynamic, operational and embeded knowledge manufacturing improvement. $\mathrm{PhD}$ Thesis. ParisTech (in French).

B. Baud-Lavigne, S. Bassetto, et B. Penz, A broader view of the economic design of the X-bar chart in the semiconductor industry, International Journal of Production Research, 2009.

Bean W. J., 1997. Variation reduction in a wafer fabrication line through inspection optimization. Thesis. M.I.T.

Bousetta, A. \& Cross, A., 2005. Adaptive sampling methodology for in-line defect inspection. Dans Advanced Semiconductor Manufacturing Conference and Workshop, 2005 IEEE/SEMI. pp. 25-31.

Chrysler Corporation, Ford Motor Company, General Motors Corporation, 1993. Potential Failure Mode and Effects Analysis, Reference Manual

Colledani, M., 2008. Integrated Analysis of Quality and Production Logistics Performance in Asynchronous Manufacturing Lines. IFAC World Congres, Seoul, pp. 1-7.

Colledani, M. \& Tolio, T., 2009. Performance evaluation of production systems monitored by statistical process control and off-line inspections. International Journal of Production Economics, In Press, DOI 10.1016/j.ijpe.2007.07.011

De Choudens, H. et al., 2000. Natural and technologic Disasters, information for a better prevention. (In French). Institut des Risques Majeurs, Grenoble.

De Magalhães, M., Costa, A. \& Moura Neto, F., 2009. A hierarchy of adaptive control charts. International Journal of Production Economics, 119(2), 271-283.

Department of defense, 1980. Procedures for performing a Failure Mode, Effects, and Criticality Analysis. MILSTD 1629A

Duncan, A.J., 1956. The Economic Design of X-bar Charts used to Maintain Current Control of a Process. Journal of the American Statistical Association, 51(274), 228-242.

Fine, C.H., 1988. A quality control model with learning effects. Oper. Res., 36(3), 437-444. 
Hsu, L. \& Tapiero, C.S., 1989. Quality control of the M/G/1 queue. European Journal of Operational Research, 42(1), 88-100.

John I.S. Hsu, A cost model for Skip-lot Destructive Sampling, IEEE Transactions on reliability, vol. 26, Avr. 1977.

N. Kumar, K. K., K. Gildersleeve, R. Abelson, C. M. Mastrangelo, et D.C. Montgomery, A review of yield modelling techniques for semiconductor manufacturing, International Journal of Production Research, vol. 23, Déc. 2006, pp. 5019-5036.

Li, J. \& Meerkov, S.M., 2009. Production Systems Engineering Springer., New York.

Lindsay, G.F. \& Bishop, A.B., 1964. Allocation of Screening Inspection Effort-A DynamicProgramming Approach. Management Science, 10(2), 342-352.

Lorenzen, T.J. \& Vance, L.C., 1986. The Economic Design of Control Charts: A Unified Approach. Technometrics, 28(1), 3-10.

M. Purdy, 2007. Dynamic, weight-based sampling algorithm.ISSM 2007. International Symposium on Semiconductor Manufacturing. pp. 1-4.

May, G.S. \& Spanos, C.J., 2006. Fundamentals of semiconductor manufacturing and process control IEEE., New Jersey: Wiley-interscience.

Mili, A. et al., 2009. Dynamic risk management unveil productivity improvements. Journal of Loss Prevention in the Process Industries, 22(1), 25-34.

Montgomery, D., 2004. Introduction to Statistical Quality Control 5 éd., John Wiley \& Sons.

Mouli, C. \& Scott, M., 2007. Adaptive Metrology Sampling techniques enabling higher precision in variability detection and control. Dans Advanced Semiconductor Manufacturing Conference, 2007. ASMC 2007. IEEE/SEMI. pp. 12-17.

Ozouf, V., 2009. How to warrant an acceptable risk level in an ever shrinking development environment and complexity increasing environment (in French). Savoie University.

Pillet, M. et al., 2007. Impact matrix for designing control plan (in French). CPI, Rabat, Maroc.

Reynolds Jr, M.R. et al., 1988. X Charts with Variable Sampling Intervals. Technometrics, 30(2), 181-192.

S.B. Gershwin \& J. Kim, 2005. Integrated Quality and Quantity Modeling of a Production Line. OR Spectrum, 27, 287-314.

Spanos, C.J., 1991. Statistical process control in semiconductor manufacturing. Microelectronic Engineering, 10(3-4), 271-276.

Tagaras, G., 1998. A survey of recent developments in the design of adaptive control charts. Journal of quality technology, 30(3), 212-231.

Tang, K. \& Tang, J., 1994. Design of Screening Procedures: A review. Journal of quality 
technology, 26(3), 209-247.

Tapiero C. S., 1987. Production learning and quality control. IIE transactions, 19(4), 362-270.

Terwiesch, C. \& E. Bohn, R., 2001. Learning and process improvement during production ramp-up. International Journal of Production Economics, 70(1), 1-19.

Tixier, J. Dusserre, G., Salvi, O., Gaston, D. 2002. Review of 62 risk analysis methodologies of industrial plants. Journal of Loss Prevention in the Process Industries, 15(4), 291-303.

Tzvi Raz, 1986. A Survey of Models for Allocating Inspection Effort in Multistage Production Systems. Journal of quality technology, 18(4), 239-247.

Verduzco, A., Villalobos, J.R. \& Vega, B., 2001. Information-based inspection allocation for realtime inspection systems. Journal of Manufacturing Systems, 20(1), 13-22.

Villacourt, M., 1992. Failure Mode and Effects Analysis (FMEA): A Guide for ContinuousVine Improvement for the Semiconductor Equipment Industry SEMATECH.

Villalobos, J.R., Foster, J.W. \& Disney, R.L., 1993. flexible inspection system for serial multistage production systems. IIE - Transactions, 25(3), 16.

Vommi, V.B. \& Seetala, M.S., 2007. A new approach to robust economic design of control charts. Applied Soft Computing, 7(1), 211-228.

Woodall, W., 1986. Weaknesses of the economic design of control charts. TECHNOMETRICS, 28(4), 408-409.

Zamaï, E. 1997, Monitoring-Command architecture for complex discrete events systems (In French), PhD thesis, Grenoble University 

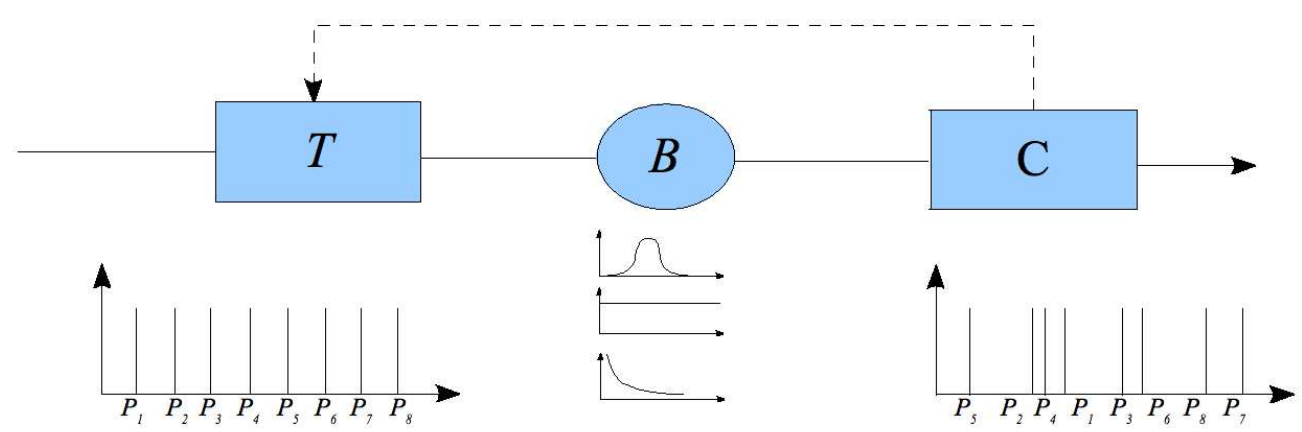

$438 \times 150 \mathrm{~mm}(72 \times 72$ DPI $)$

http://mc.manuscriptcentral.com/tprs Email: ijpr@lboro.ac.uk 
1

2

3

4

5

6

7

8

9

10

11

12

13

14

15

16

17

18

19

20

21

22

23

24

25

26

27

28

29

30

31

32

33

34

35

36

37

38

39

40

41

42

43

44

45

46

47

48

49

50

51

52

53

54

55

56

57

58

59

60

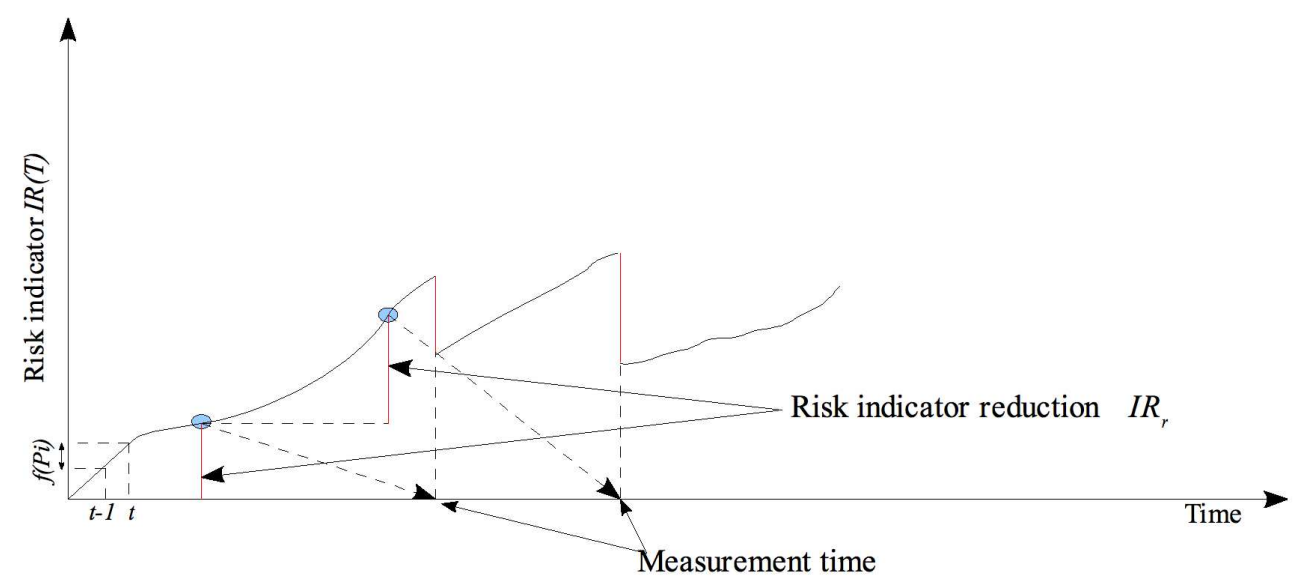

$613 \times 278 m m(72 \times 72$ DPI $)$ 


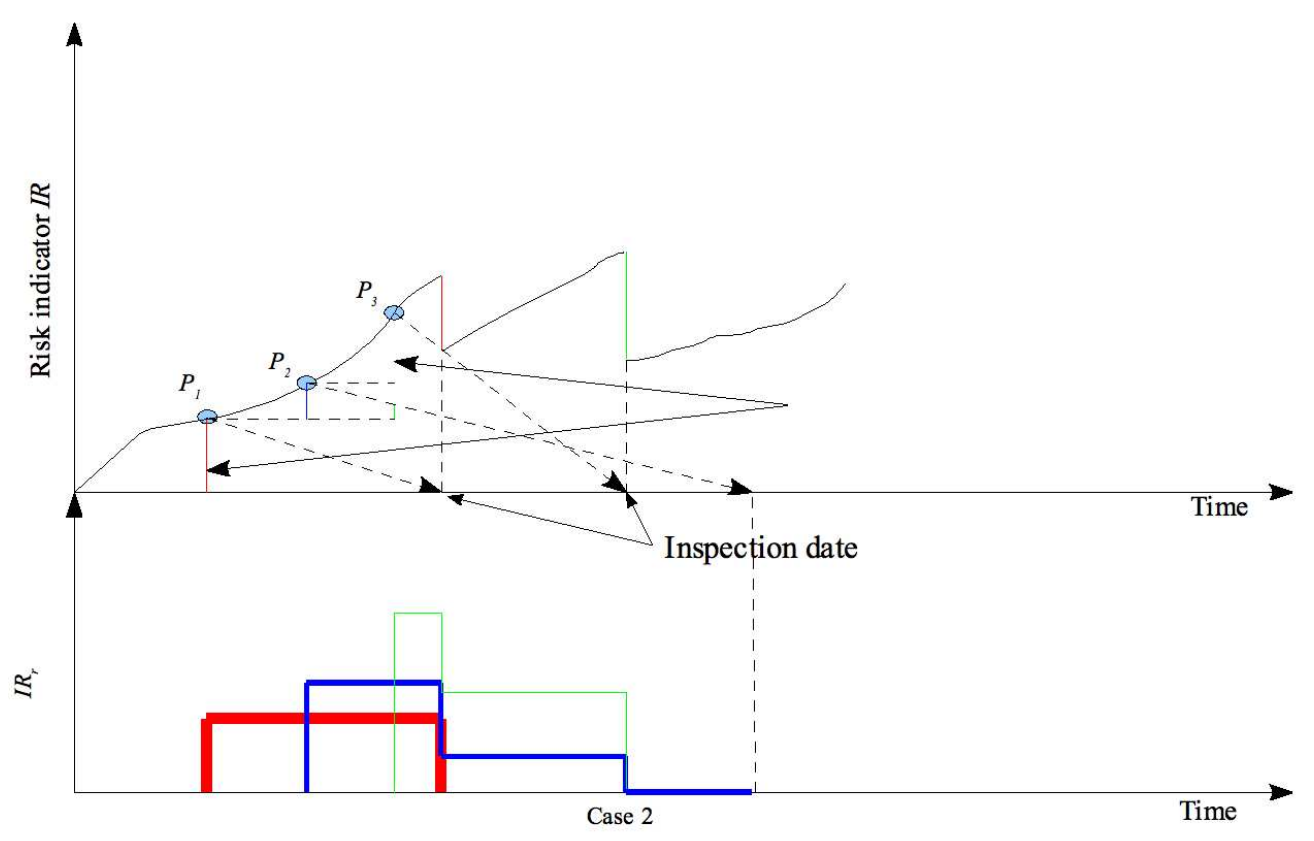

$445 \times 290 \mathrm{~mm}(72 \times 72$ DPI $)$ 


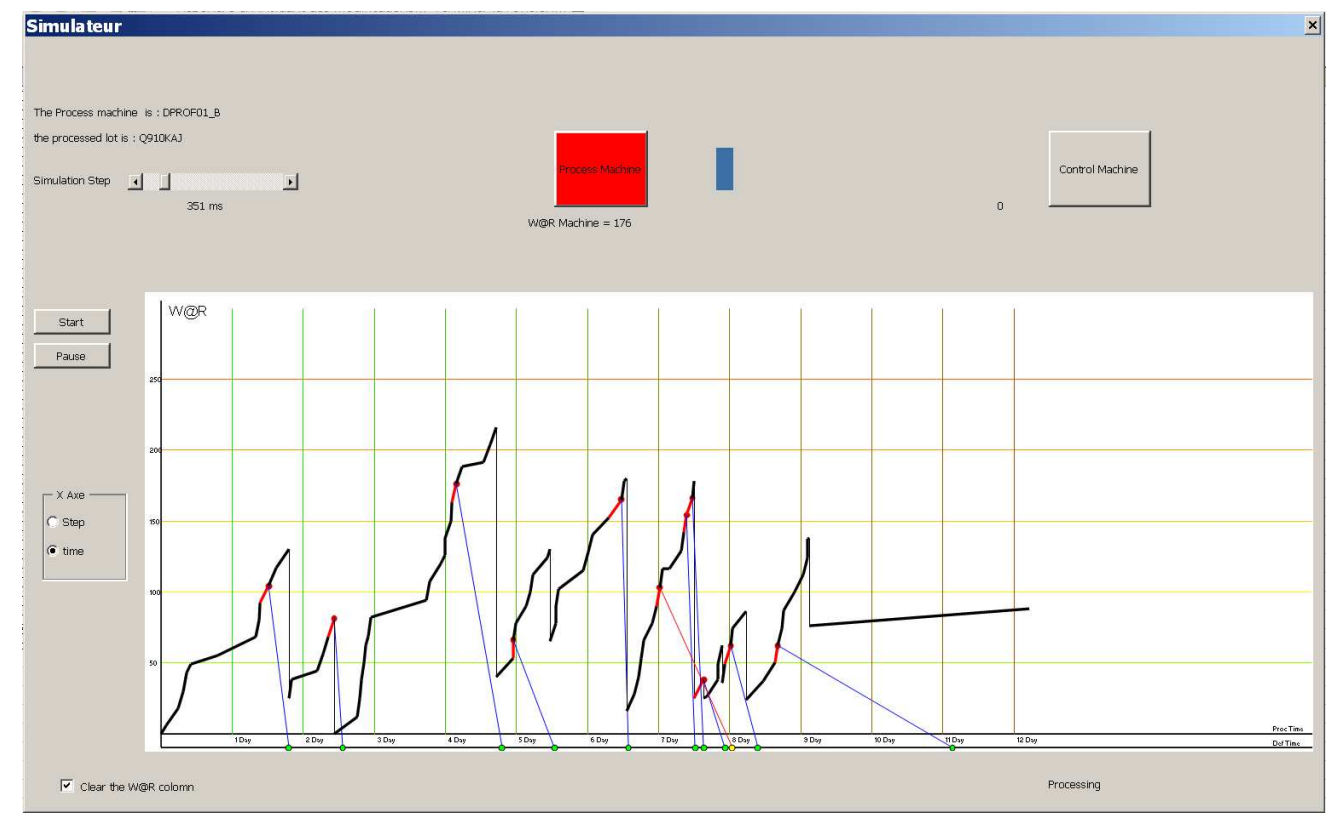

$323 \times 199 m m(120 \times 120$ DPI $)$

1

2

3

4

5

6

9

10

11

12

13

14
15

16

17

18

19

20

21

22

24

25

26

27

28

34

35

36

37

38

39

40

41

42

43

44

45

46

47

48

49

50

51

52

53

54

55

56

57

58

59

60

http://mc.manuscriptcentral.com/tprs Email: ijpr@lboro.ac.uk 
International Journal of Production Research

Page 26 of 25

1
2
3
4
4
5
6
7
8
9
9
10
11
12
13
14
15
16
17
18
19
20
20
21
22
23
24
24
25
26
27
28

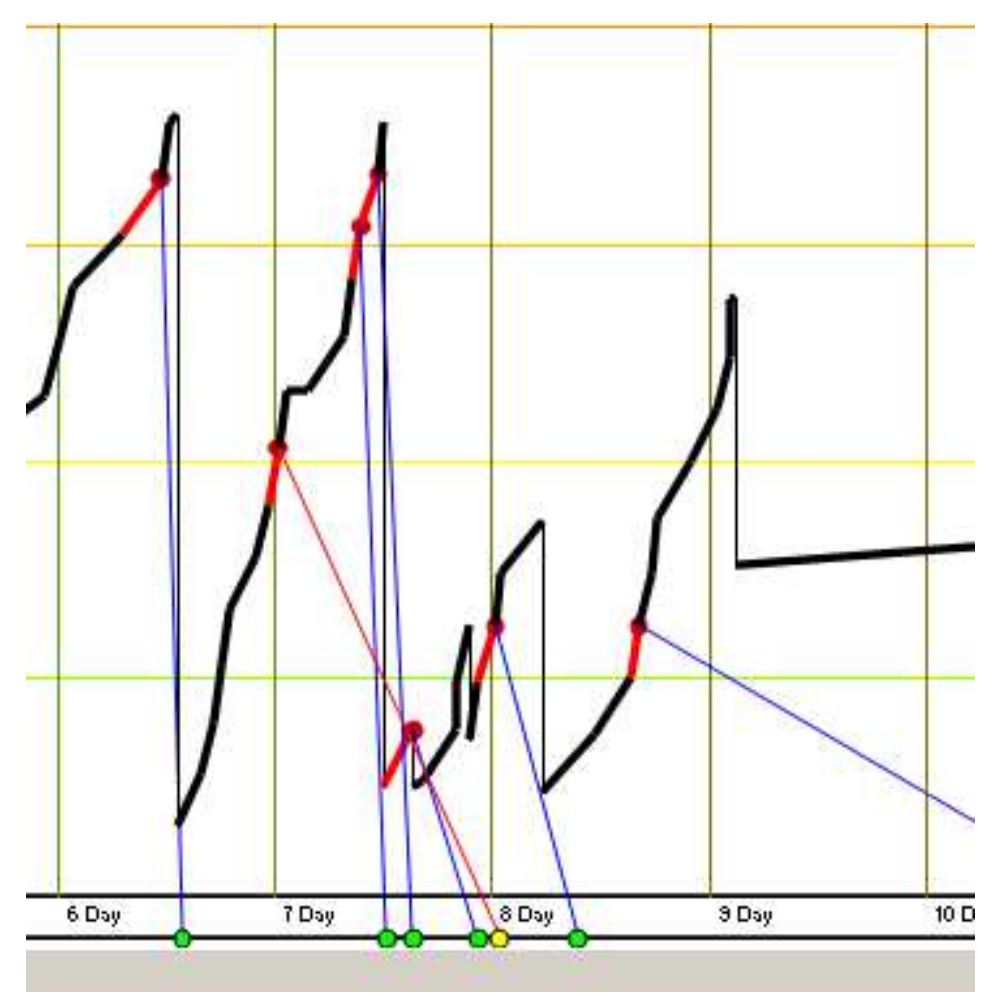

$77 \times 78 \mathrm{~mm}(120 \times 120 \mathrm{DPI})$

http://mc.manuscriptcentral.com/tprs Email: ijpr@lboro.ac.uk 